\title{
PHYSICO-CHEMICAL DIVERSITY AND MICROBIAL BURDEN IN FOUR DATES PALM (PHOENIX DACTYLIFERA L.) FRUIT VARIETIES GROWN IN AGRO-CLIMATIC CONDITION OF TURBAT, BALOCHISTAN-PAKISTAN
}

\author{
ASlAM, A. ${ }^{1}$ - LEGHARI, S. K..$^{*}$ - ASRAR, M. ${ }^{1}-$ SAEED, S. $^{1}-$ ShAFI, M. ${ }^{2}-$ SIDDIQI, M. F. ${ }^{4}-$ \\ SUMALANI, M. A. ${ }^{1}-$ MAHAM, F. ${ }^{1}-$ MERRI, A. A. ${ }^{3}$ \\ ${ }^{1}$ Department of Botany, University of Balochistan, Quetta 87300, Pakistan \\ (phone: +92-81-921-1264) \\ ${ }^{2}$ Faculty of Pharmacy, University of Balochistan, Quetta 87300, Pakistan \\ ${ }^{3}$ Department of Statistics, University of Balochistan, Quetta 87300, Pakistan \\ ${ }^{4}$ Department of Botany, University of Karachi, Sindh 75270, Pakistan \\ *Corresponding author \\ e-mail:saadbotany@yahoo.com,drsaadullahleghari@gmail.com \\ (Received $1^{\text {st }}$ Feb 2019; accepted $8^{\text {th }}$ Apr 2019)
}

\begin{abstract}
The aim of this study was to measure the quality indices (physico-chemical and microbial assessment) of four popular date palm fruits (Phoenix dactylifera L.) varieties (Begamjangi, Haleeni, Dashtri and Peshnah) grown in ecologically same agro climatic condition of Turbat Balochistan, Pakistan. Different date palm characteristics including; harvesting time, color and taste of fruits, diversity in fruit, stone weight, length and diameter, variation in chemical composition, sugar, minerals and amino acids contents were recorded by standard methods. Results indicated that there was slightly to highly significant variations among the investigated parameters in different cultivars. Further that microbial burden (cfu/g) on four fruit sizes classes (large, small, medium and mixed) in three fruit processing techniques (unpressed-unpitted, pressed-pitted and unpressed-pitted date fruits) were examined. The results revealed that the different date varieties showed different load of microbial infections. On the basis of all investigated parameters the fruit performance index (FPI) and valuation classes were calculated. The consequences indicated that the Begamjangi score highest grade point (6) and stood in excellent class, followed by Haleeni with grade point 4.0 and categorized in good class. Other two date cultivars Dashtri and Peshnah score $2.0 \& 1.0$ grade points and classified into poor and very poor group of date palm fruits, respectively.

Keyworlds: date cultivars, productivity, sugar and mineral contents, bacterial infection, fruit performance index (FPI), fruit size classes
\end{abstract}

\section{Introduction}

The date fruit (Phoenix dactylifera L.) is an important food product and extensively cultivated all over the world for its edible fruits. It is a monocotyledonous belongs to the family Arecaceae. Mostly cultivated in semi-arid regions of the world (Ashraf and Hamidi-Esfahani, 2011). Fruit is highly nutritious with delicious taste and a basic part of human diet (Vayalil, 2002). Date fruit is constituted high percentage of carbohydrates (glucose and fructose), proteins, vitamins, fats, dietary fibers, minerals and low amount of starch. Their Chemical composition depends on cultivar type, fruit developmental stage and agro-climatic conditions (Al-farsi et al., 2005; Al-farsi and Lee, 2008; Safi et al., 2009; Baliga et al., 2011). Pakistan is well known for its date industry with annual production of 70 thousand tons (Anonymous, 2012), contributing 10.3\% of total world's 
production. Aseel, Dhakki, Begumjungi and Koharba are amongst the most important native date palm varieties. Many other local cultivars are also grown in different agroecological zones of Pakistan (Iqbal et al., 2016). The farmers have denominated the cultivars on the basis of shape and color of the fruits or the presence of specific locations (Ahmed et al., 2011). The date palm is selected for cultivation on the basis of better fruit quality and post-harvest life. Based on the botanic interpretation, there are about 244 cultivars in Morocco, 250 in Tunisia, 370 in Iraq, 400 in Iran (Zaid and de Wet, 2002), 400 in Sudan (Osman, 1984), 325 in Pakistan (Botes and Zaid, 2002; Jamil et al., 2010). About 5000 different date palm cultivars are known to present worldwide (Jaradat and Zaid, 2004).

Quality standards of dates must include chemical, physical and sensory attributes. Date varieties significantly vary in terms of their chemical composition. The variation in chemical composition affects the structural, sensory and textural properties of fruits (Rahman and Al-Farsi, 2005). The function of sensory analysis is to provide measurements that are accurate, precise, and valid (Piggott, 1995) and variation in sensory attributes is due to the genetic differences and variable growth conditions. There is a considerable diversity within date palm cultivars. Although, accurate characterization of cultivars need a huge set of morphological as well as biochemical and molecular (isozymes) markers. Moreover, vegetative characteristics, phenotypic diversity and phylogenetic relationship are important to evaluate date palm ecotypes (Haider et al., 2015). This significant plants are endangered through hereditary corrosion, change of agrarian land, irritant and infections. Numerous investigations have emphasized this concern (Zehdi et al., 2005, 2012). Hammadi et al. (2009) and Ahmed et al. (2011) used phenotypic data to classify dissimilar date palm cultivars. Wills et al. (1998) stated that, with respect to consumers, the important quality criteria of a product are appearance (including color, size, and shape, condition and absence of defects), mouth feel or texture, flavor, and nutritional value. So due to the importance of date fruits a number of countries have formulated and applied date standards at the national level both for locally produced and imported dates. So there are many date standards that include both local and international specifications. They contributed to the ease of global trade for dates. However, the standards do not emphasize some important quality parameters of these fruits.

There are no extensive studies on the quality indices and standards for the most abundant and commercially important date palm fruits (Begamjangi, Haleeni, Dashtri and Peshnah) in Turbat Balochistan, Pakistan. Therefore, this study is designed to assess the physico-chemical and microbial estimation of four popular and important date cultivars.

\section{Materials and methods}

\section{Plant material and samples collection}

Fruit samples were collected from four date palm varieties from same ecological conditions in regional date field of Turbat, Balochistan. These date cultivars were Begamjangi, Haleeni, Dashtri and Peshnah. Study was based on fruit physiochemical characters. Analysis were carried out on 40 randomly selected trees (10 from each cultivar). A total of $20.0 \mathrm{~kg}$ of fruit samples from ten randomly selected trees of each cultivar were collected separately at maturity stage (August to September) during 2018. Samples were cleaned, washed and packaged in polyethylene bags inside $20 \mathrm{~kg}$ cartons, 
and preserved in a refrigerator at $5^{\circ} \mathrm{C}$ until experimental tests were performed. Typical morphological image of the experimental cultivars are shown in Fig. 1. Further that on the basis of harvesting time the date palm varieties were classified in to early, mid and late variety (Table 1).

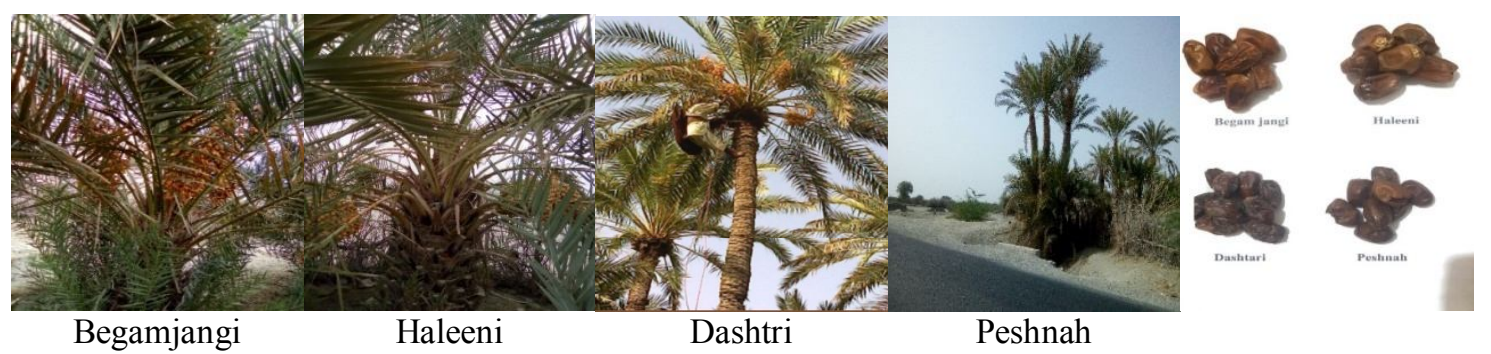

Figure 1. Picture of investigated dry date palm varieties

Table 1. Indication of harvesting time, fruit color, and taste in four date palm varieties

\begin{tabular}{|c|c|c|c|c|}
\hline \multirow{2}{*}{ Date Varity } & \multicolumn{4}{|c|}{ Parameters } \\
\hline & Harvesting time & Type & Fruit colour & Taste \\
\hline $\begin{array}{l}\text { Begamjangi } \\
\text { Haleeni } \\
\text { Dashtri } \\
\text { Peshnah }\end{array}$ & $\begin{array}{l}20^{\text {th }} \text { August }-20^{\text {th }} \text { September } \\
\text { After } 20^{\text {th }} \text { September } \\
20^{\text {th }} \text { August }-20^{\text {th }} \text { September } \\
20^{\text {th }} \text { July- } 20^{\text {th }} \text { August }\end{array}$ & $\begin{array}{l}\text { Med verity } \\
\text { Late verity } \\
\text { Med verity } \\
\text { Early verity }\end{array}$ & $\begin{array}{l}\text { Light yellow } \\
\text { Yellow } \\
\text { Dark brown } \\
\text { Light yellow }\end{array}$ & $\begin{array}{l}\text { Delicious } \\
\text { Tasteful } \\
\text { Slightly tasty } \\
\text { Poor taste }\end{array}$ \\
\hline
\end{tabular}

\section{Physiochemical character study}

Fruit and stone weight was assessed by analytical balance and calculated as a mean of randomly designated 30 mature fruits from each cultivar as used by Lemine et al. (2014). Fruit and stones length and breadth were noted by using complete numerical microelectronic Vernier-caliper as the method used by Mughal et al. (2018). Fruit moisture/water contents were measured by dehydrating $5 \mathrm{~g}$ date pulp in vacuum oven for $24 \mathrm{hr}$ at $70^{\circ} \mathrm{C}$ by using the following formula: \% water = [(initial weight- dry weight) $\times$ 100]/initial weight] (Leghari et al., 2017). Fruit color was measured by color difference meter and the measurements were performed on 10 individual randomly selected fruits from each cultivar (a total of 120 fruits) with three replicate (Aleid et al., 2014). Entire nitrogen was measured by the Kjeldahl method as described by AOAC (1995) and protein was expressed as the overall factor 6.25 (Laurey, 1997). The entire lipid contents were determined through the methods as described by Folch et al. (1957). Water activity was determined in a water activity meter (Rotronic) and ash level was measured from the differences after warming softened date sample in an oven at $600^{\circ} \mathrm{C}$ for $8 \mathrm{~h}$. Electrical conductivity (EC) was noted from dry sieved sample. $20 \mathrm{~g}$ dry date sample was stimulated by $50 \mathrm{ml}$ distilled water and left-hand to equilibrate for $40 \mathrm{~min}$ and then filter the mixture. The EC of each variety sample was measured by using the electrical conductivity meter (Crison Basic 30+EC-Meter, 08323 Alella-Bacrelona made in EU). Sugars contents from soaked date pulp samples were measured with water at $85^{\circ} \mathrm{C}$ and it was computed through the 3,5-dinitrosallicylic acid technique as described by Laurey (1997). Overall sugar (Sucrose, glucose, and fructose) contents were noted by high performance liquid chromatography (HPLC) according to the methods of AOAC (1995). Date samples were spiked by several mixtures of average 
sugars (1-5 ppm) to display retrieval and the sugar content was intended from highest area of measurement according to the method of Langemeier and Rogers (1995). Minerals (calcium, phosphorus, potassium, sodium and magnesium) contents were determined through atomic absorption spectrophotometer and expressed by $\mathrm{mg} / 100 \mathrm{~g} \mathrm{dw}$. Different obtainable amino acids (proline, glycine, histidine, valine, leucine, serine, methionine, isoleucine, tyrosine, phenylalanine, lysine and alanine) were examined through the technique as described by Laurey (1997). Date fruit samples were hydrolysis by vapors $\mathrm{HCl}$ and standard for $20 \mathrm{hr}$ at $110^{\circ} \mathrm{C}$. After that the date samples were extracted on poly-vinylidene difluoride with $100 \mu \mathrm{L}$ of $40 \%$ aceto-nitrile and $0.5 \%$ trifluoroacetic acid for three times. The excerpts were then dehydrated entirely in a Rapidity Vac earlier re-suspension in sample buffer. After that the samples and standards were examined in a Beckman system 6300 (Laurey, 1997). Different amino acids were articulated in to $\mathrm{mg} / 100 \mathrm{~g} \mathrm{dw}$. Total acidity was measured by using $10 \mathrm{ml}$ of fruit juice which were titrated against $0.1 \mathrm{M}$ sodium hydroxide solution by the utilization of phenolphthalein as an indicator (AOAC, 1995). Total acidity was calculated according the fallowing formula: Volume $\mathrm{NaOH}(\mathrm{ml}) \times 0.1 \mathrm{M} \times 0.067$ and expressed as malic acid content. The $\mathrm{pH}$ measurement was done by calibrated digital $\mathrm{pH}$ meter (CyberScan 510 USA).

\section{Classification of fruits into fruit size classes}

Fruits were classified into four size classes including; large, small, medium and mixed were arranged according to the fruits weight (g). Fuit size classes were calculated by the following formula: large $=$ weight $>x$ gram; medium $=x$ gram $>$ weight $>y$ gram; and small $=$ weight $<$ y gram. For four fruit size classes (large, small, medium and mixed) and three fruit processing methods (unpressed-unpitted, pressed-pitted and unpressedpitted) a $4 \times 3$ factorial treatment strategy was acquired. Where the term "pressed" mentions to dates that were compacted into layers through mechanical force and unpressed refers to dates that were packed without powered presser or density. Pressing of entire dates was made with packing in a flexible sealed. The term "pitted" used to date palm fruits whose seeds/stones were removed. In order to remove the pit a sharp knife was used for pitting of whole dates and the date fruits were cut from end to end. As per outcome, there were 12 samples from each date variety and a total number of 36 samples. Microbial burden was measured in the study through Coliform, Moulds and Yeast and total bacterial counts.

\section{Microbial burden study}

Pour plate method was used to count the aerobic mesophilic bacteria on plate count agar dishes. These plates were incubated for 3 days at $35^{\circ} \mathrm{C}$. From the sample, the counts were expressed as colony forming units per gram (cfu/g). Fruit samples were aseptically destoned by utilizing sterilized pincers and microbial burden was calculated for the skin. Skin samples were weighed $10 \mathrm{~g}$ into sterilized stomacher bags and $90 \mathrm{ml}$ of sterilized peptone water. For homogenization of mixture a stomacher was used for 50 seconds and aliquots $(1.0$ or $0.1 \mathrm{ml})$ plated out in duplicate as 10 -fold dilutions in peptone water. The pour plate/overlay method was used to count the coliforms on Vilet Red Bile Agar (VRBA). The plates were incubated for 48 hours at $35^{\circ} \mathrm{C}$. The round, purple-red colonies $(0.5-2 \mathrm{~mm}$ diameter) surrounded by purple-red haloes on VRBA plates were counted as coliforms. Spread plate method was used to culture the yeasts and moulds on 
potato dextrose agar. Yeasts plates were incubated for 3 days at $35^{\circ} \mathrm{C}$ and for moulds it was incubated 5-7 days at 25-30 C (Atlas, 2004; Abekhti et al., 2013).

\section{Fruit Quality Assessment}

Fully ripened fruits were harvested from four selected varieties and dried until a constant weight was reached (moisture content 12 to $25 \%$ ). Fruit weight, stone weight, reducing sugar, over all minerals, moisture \%/water activity and microbial burden hardy were determined according to the standard methods as described above in this research methodology. Acidity, Taste and flavor of fruit was tested by a panel of six experienced judges (one from food department, two date farmers, two Ph.D. Professor from botany department university of Balochistan Quetta and other one from agriculture department) from and values/scales were given from 1-5/1-10 (Leghari et al., 2019). 10 fruits from each varieties were randomly selected for taste and flavor for each expert/judges.

\section{Fruit performance index (FPI) through fruit quality and valuation Classes}

For the date fruit performance index $(F P I)$ the methods described by Prajapati and Tripathi (2008) and Leghari et al. (2019) was used. FPI values were calculated by combining the different fruit quality parameters (fruit weight, stone weight, taste of fruit, acidity, reducing sugar, over all minerals, moisture \%/water activity and microbial burden hardy) of four date palm varieties based on character grading $(+$ or -$)$ fixed to the plant.

\section{Statistical analysis}

Statistical analysis of data collected during the course of each trial was performed by analysis of variance (ANOVA) to determine the interaction effects among the main factors using SPSS software version 16.0 and for the comparison between the means of treatments duncans multiple-range test $(P=0.05)$ was used (Steel and Torrie, 1980).

\section{Results and discussion}

Results shown in Table 1 indicated that Begumjangi was designated med variety with light yellow fruit color and delicious taste. Haleeni was noted late variety with yellow fruit color and tasteful. Dashtri was found med variety with Dark brown fruit color and slightly tasty. Peshnah was found early variety with light yellow fruit color and poor taste. The variation in harvesting time, fruit color and taste in different date varieties was also noted previously (Abekhti et al., 2013; Aleid et al., 2014). They reported a great differences in date fruits color from different date varieties of Saudi Arabia.

\section{Productivity variation in date varieties}

Results in Table 2 indicated statistically significant variation in average weight, length and breadth of fruits and stone in four date palm varieties grown in agro climatic condition of Turbat. Fruit and stone weight, length and breadth is directly related to productivity of a cultivar. In this study the average weight, length and breadth were noted from the ranged $2.75-8.57 \mathrm{~g} /$ fruit, $2.7-3.1 \mathrm{~cm} /$ fruit \& $1.3-1.9 \mathrm{~cm} /$ fruit, respectively. Haleeni showed maximum average fruit weight and Dashtari minimum and the highest length of fruit was noted for Begamjangi and lowest for Dashtari. The 
uppermost fruit breadth was presented by Begamjangi and lowermost by Haleeni. The average weight and length of stone were ranged $0.54-0.66 \mathrm{~g} /$ fruit fw and $1.7-1.9$ $\mathrm{g} /$ fruit fw, respectively, while stone breadth was noted same $(0.7 \mathrm{~g} / \mathrm{fruit} \mathrm{fw})$ in all investigated verities. The extreme average weight and length of stone was found in Dashtari and Peshnah and least in Haleeni and Dashtri, respectively. Variation in these parameters were also observed by Ragab et al. (2011). They reported differences in fruit weight at different stages in diverse variety. Variation in these parameters in diverse varieties led to the variation in total yield.

Table 2. Diversity in average weight, length and diameter of fruits and stones in four date palm varieties

\begin{tabular}{c|c|c|c|c|c|c|c}
\hline $\begin{array}{c}\text { Date palm } \\
\text { variety }\end{array}$ & Fruit weight & Stone weight & Fruit length & Stone length & Fruit breadth & Stone breadth & $\begin{array}{c}\text { P } \\
\text { value }\end{array}$ \\
\hline Begamjangi & $6.87^{\mathrm{ab}}$ & $0.60^{\mathrm{ab}}$ & $3.1^{\mathrm{a}}$ & $1.8^{\mathrm{a}}$ & $1.9^{\mathrm{a}}$ & $0.7^{\mathrm{a}}$ & 0.031 \\
Haleeni & $8.57^{\mathrm{a}}$ & $0.54^{\mathrm{b}}$ & $2.9^{\mathrm{a}}$ & $1.8^{\mathrm{a}}$ & $1.3^{\mathrm{b}}$ & $0.7^{\mathrm{a}}$ & 0.021 \\
Dashtri & $2.75^{\mathrm{b}}$ & $0.66^{\mathrm{a}}$ & $2.7^{\mathrm{a}}$ & $1.7^{\mathrm{a}}$ & $1.5^{\mathrm{ab}}$ & $0.7^{\mathrm{a}}$ & 0.022 \\
Peshnah & $4.00^{\mathrm{ab}}$ & $0.64^{\mathrm{b}}$ & $2.8^{\mathrm{a}}$ & $1.9^{\mathrm{a}}$ & $1.5^{\mathrm{ab}}$ & $0.7^{\mathrm{a}}$ & 0.031 \\
$P$ value & 0.036 & 0.002 & 0.457 & 0.468 & 0.034 & 1.00 & \\
\hline
\end{tabular}

Each value is the mean of 30 replicates, Different letters in the same column and raw indicate statistically significant differences (significance level $P=0.05$ )

\section{Diversity in Chemical composition of date varieties}

Consequences displays slightly to highly significant diversity in various chemicals (Moisture, Protein, Lipid, Ash contents and Water activity) composition in four date palm fruits varieties. Results indicated that the moisture contents in four investigated date palm fruits varieties was in ranged between $15.4-24.3 \%$ and the highest moisture content was found in Peshnah fruits and lowest in Begumjangi. Protein and lipid contents were in between $2.15-3.24 \mathrm{~g} / 100 \mathrm{~g}$ dw, $0.13-0.54 \mathrm{~g} / 100 \mathrm{~g}$ dw, respectively. The uppermost protein and lipid content were showed by Begumjangi fruits and minimum by Dashtari and Peshnah, respectively. The ash contents and water activity in all investigated date varieties were recorded in the range of $1.23-3.52 \mathrm{~g} / 100 \mathrm{~g} \mathrm{dw}$ and $0.421-0.675 \mathrm{aw}$, respectively. The highest ash contents were originate by Begumjangi, whereas lowest by Peshnah and Water activity was exhibited highest in Peshnah and lowest in Begumjangi (Table 3). The outcomes of this study are analogous to other researchers as they testified before (Elleuch et al., 2008; Assirey, 2015), through approximately variances associated to date cultivar and agro-climatic and environmental circumstances (Myhara et al., 1999; Biglari et al., 2009). It has been also described earlier that the dates are not a decent basis of protein (Al-Hooti et al., 1997).

\section{Sugar contents in date fruits}

The sucrose, glucose, fructose, Reducing sugar contents and ratio between glucose and fructose were found from ranged $2.00-4.24,35.5-48.5,27.0-35.5,62.5-84.0$ and $1.31-1.37 \mathrm{~g} / 100 \mathrm{~g} \mathrm{dw}$, respectively in four different date varieties. The maximum glucose, fructose, reducing sugar and ratio between glucose and fructose was shown by Begumjangi and minimum Peshnah. Highest content of sucrose was noted in Peshnah and lowest in Begumjangi fruits (Table 4). Similar observation was also noted by Assirey (2015). Richness in reducing sugars (glucose and fructose) is being significantly decrease its sucrose content (Elleuch et al., 2008; Besbes et al., 2009). Statistical 
analysis exhibited that sucrose, glucose and reducing sugar were found slightly significant different between the four examine date varieties, while fructose content and ratio between glucose and fructose were non-significant between four date varieties (Table 4). Non-significant variation in these parameters were also reported by Assirey (2015) between Ajwa, Shalaby, Suqaey, Sukkari, Burni, Mabroom and Anabarah and between Khodari and Safawy.

Table 3. Diversity of chemical composition in four different date palm fruits

\begin{tabular}{c|c|c|c|c|c}
\hline Variables & \multicolumn{4}{|c|}{ Date Varieties } & \multirow{2}{*}{ P value } \\
\hline Fruit moisture (\%) & Begamjangi & Haleeni & Dashtri & Peshnah & \\
Protein (g/100 g dw) & $15.4^{\mathrm{b}}$ & $18.3^{\mathrm{b}}$ & $23.3^{\mathrm{a}}$ & $24.3^{\mathrm{a}}$ & 0.035 \\
Lipid (g/100 g dw) & $3.24^{\mathrm{a}}$ & $2.16^{\mathrm{b}}$ & $2.15^{\mathrm{b}}$ & $2.54^{\mathrm{b}}$ & 0.044 \\
Ash (g/100 g dw) & $0.54^{\mathrm{a}}$ & $0.51^{\mathrm{a}}$ & $0.34^{\mathrm{b}}$ & $0.13^{\mathrm{c}}$ & 0.000 \\
Water activity (aw) & $3.52^{\mathrm{a}}$ & $2.01^{\mathrm{ab}}$ & $2.35^{\mathrm{ab}}$ & $1.23^{\mathrm{b}}$ & 0.025 \\
\hline
\end{tabular}

Each value is the mean of three replicate, different letters in the same column indicate statistically significant differences (significance level $P=0.05$ )

Table 4. Sugar contents in four different date palm fruits varieties

\begin{tabular}{c|c|c|c|c|c}
\hline Variables & \multicolumn{4}{|c|}{ Date palm varieties } & \multirow{2}{*}{ P value } \\
& Begam Jangi & Haleeni & Dashtri & Peshnah & \\
\hline Sucrose (g/100g dw) & $2.00^{\mathrm{b}}$ & $2.75^{\mathrm{b}}$ & $3.45^{\mathrm{ab}}$ & $4.24^{\mathrm{a}}$ & 0.013 \\
Glucose (g/100g dw) & $48.5^{\mathrm{a}}$ & $43.6^{\mathrm{ab}}$ & $40.7^{\mathrm{ab}}$ & $35.5^{\mathrm{b}}$ & 0.024 \\
Fructose (g/100g dw) & $35.5^{\mathrm{a}}$ & $33.4^{\mathrm{ab}}$ & $30.2^{\mathrm{ab}}$ & $27.0^{\mathrm{b}}$ & 0.042 \\
Reducing sugar (g/100g dw) & $84^{\mathrm{a}}$ & $77^{\mathrm{ab}}$ & $70.9^{\mathrm{ab}}$ & $62.5^{\mathrm{b}}$ & 0.010 \\
Glu/Fru (g/100g dw) & $1.37^{\mathrm{a}}$ & $1.31^{\mathrm{a}}$ & $1.35^{\mathrm{a}}$ & $1.31^{\mathrm{a}}$ & 0.145 \\
\hline$P$ value & 0.000 & 0.004 & 0.007 & 0.002 & \\
\hline
\end{tabular}

Each value is the mean of five replicate, different letters in the same column and raw indicate statistically significant differences (significance level $P=0.05$ )

It is authenticated that dates are vital bases of sugar. In present investigation the overall total sugar was recorded from the ranged of $66.74-86 \mathrm{~g} / 100 \mathrm{~g}$ dw in four date palm varieties. The maximum content was noted in Begumjangi, which followed by Haleeni (79.75 g/100g dw), Dashtari (74.35 g/100g dw) and minimum was found in Peshnah fruit. Statistical analysis indicated that there was significant variation in total sugar contents among four investigated date varieties (Fig. 2). The variation in total sugar by different cultivar were also noted by other authors. Elleuch et al. (2008) and Besbes et al. (2009) reported variation in total sugar contents $(81.6-88.4 \%, 72.8$ $79.1 \%$ and $72.8-79.1 \%$ and $78.3-87.6 \%$ ), in different date varieties. Contrary to this, Non-significant variation in total sugar was reported by Assirey (2015) between Khodari, Anabarah, Sukkari, Suqaey and Burni and between Ajwa, Shalaby, Safawy and Labanah.

\section{Mineral diversity in date fruits varieties}

The mean contents of calcium, phosphorous, potassium, sodium and magnesium were found in ranged from 120 - 180, 12.5 - 25.02, 276 - 450.5, 4.6 - 7.05 and 55.4 $120.4 \mathrm{mg} / 100 \mathrm{~g} \mathrm{dw}$, respectively. The maximum calcium, phosphorus, potassium, sodium and magnesium were recorded in Begumjangi and minimum in Peshnah fruits. 
Statistical analysis indicated that calcium, potassium, sodium and magnesium were found slightly to highly significant different in four investigated date palm varieties, while phosphorus showed non-significant variation (Table 5). The mean contents of overall minerals was found in the ranged $156.7-93.7 \mathrm{mg} / 100 \mathrm{~g}$. The highest overall minerals contents was recorded in Begumjangi which followed by Haleeni (130.144 $\mathrm{mg} / 100 \mathrm{~g})$ then Dashtri (108.1 mg/100 g) and least in Peshnah (Fig. 2). Variation in mineral contents in different date cultivar were also reported by Ragab et al. (2011) and Assirey (2015). They found differences in mineral contents between different date varieties such as; Khodari, Anabarah, Sukkari, Suqaey and Burni and between Ajwa, Shalaby, Safawy and Labanah. The consequences of our study supported by authors of numerous other investigation. They indicated that date fruits had appropriate level of different minerals (calcium, potassium and phosphorus) which are essential for human bodies (Sawaya et al., 1983; Gasim, 1994). The differences in minerals especially; magnesium and sodium contents might be clarified by the influences such as variety, soil types and environmental conditions.

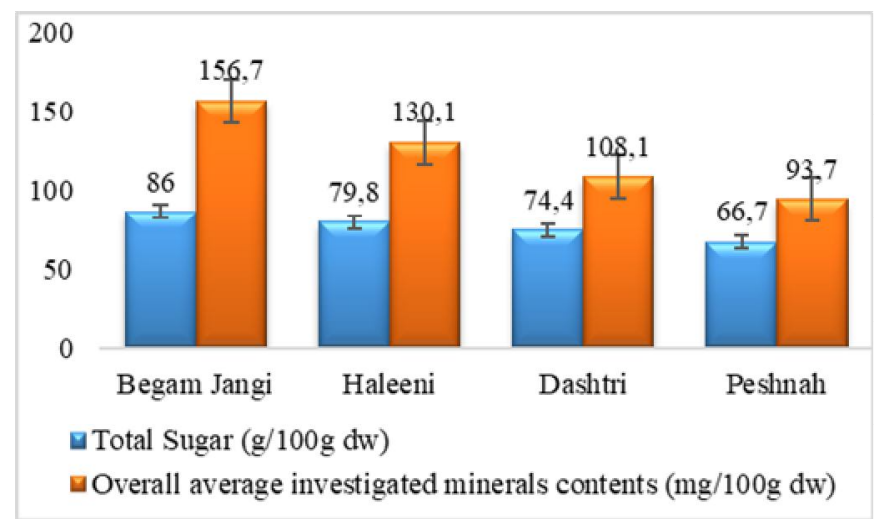

Figure 2. Total Sugar contents $(g / 100 g d w)$ and Overall Mineral contents $(\mathrm{mg} / 100 \mathrm{~g} d w)$ in four different date palm fruits varieties

Table 5. Mineral composition in four different date palm fruits varieties

\begin{tabular}{|c|c|c|c|c|c|}
\hline \multirow{2}{*}{ Minerals variables } & \multicolumn{4}{|c|}{ Date varieties } & \multirow{2}{*}{$P$ value } \\
\hline & Begamjangi & Haleeni & Dashtri & Peshnah & \\
\hline Calcium (mg/100g dw) & $180.4^{\mathrm{b}}$ & $150.2^{b}$ & $142.0^{\mathrm{b}}$ & $120^{b}$ & 0.002 \\
\hline Phosphorus (mg/100g dw) & $25.02^{\mathrm{c}}$ & $19.3^{\mathrm{c}}$ & $15.8^{\mathrm{c}}$ & $12.5^{\mathrm{c}}$ & 0.004 \\
\hline Potassium (mg/100g dw) & $450.5^{\mathrm{a}}$ & $370^{\mathrm{a}}$ & $310^{\mathrm{a}}$ & $276^{\mathrm{a}}$ & 0.037 \\
\hline Sodium (mg/100g dw) & $7.05^{\mathrm{d}}$ & $6.22^{\mathrm{d}}$ & $6.03^{\mathrm{d}}$ & $4.6^{\mathrm{d}}$ & 0.018 \\
\hline Magnesium $(\mathrm{mg} / 100 \mathrm{~g} \mathrm{dw})$ & $120.4^{\mathrm{b}}$ & $105^{\mathrm{b}}$ & $66.6^{\mathrm{b}}$ & $55.4^{\mathrm{b}}$ & 0.000 \\
\hline$P$ value & 0.002 & 0.000 & 0.000 & 0.000 & \\
\hline
\end{tabular}

Each value is the mean of five replicate, different letters in the same column and different raws indicates statistically significant differences at significance level $P=0.05$

\section{Amino Acids Contents}

Calculated mean values of proline, glycine, histidine, valine, leucine, serine, methionine, isoleucine, tyrosine, phenylalanine, lysine and alanine in investigated varieties were found ranged between $73-114,89-93,25-10,60-77,51-86,54-62$, $10-25,35-48,10-20,46-55,44-70$ and $75-86 \mathrm{mg} / 100 \mathrm{~g} \mathrm{dw}$, respectively. The 
maximum histidine, leucine, methionine, isoleucine, tyrosine and lysine were shown by Begumjangi and minimum by Peshnah fruits. Glycine and alanine were found highest in Haleeni and lowest in Begumjangi and Peshnah fruits, respectively. However, Peshnah showed uppermost values of serine, phenylalanine, proline and valine and lowermost showed by Haleeni and Begumjangi respectively (Table 6). The aspartic acid and overall average amino acid contents were recorded in ranged $105-165$ and 22.7 - 56.7 $\mathrm{mg} / 100 \mathrm{~g}$ in four investigated date palm varieties.

Table 6. Amino Acids Contents ( $\mathrm{mg} / 100 \mathrm{~g} \mathrm{dw}$ ) in four different date palm fruits varieties

\begin{tabular}{c|c|c|c|c|c}
\hline \multirow{2}{*}{ Amino acids variables } & \multicolumn{4}{|c|}{ Date Variety } & \multirow{2}{*}{ P value } \\
\hline Proline & Begamjangi & Haleeni & Dashtri & Peshnah & \\
Glycine & $73^{\mathrm{b}}$ & $82^{\mathrm{b}}$ & $94^{\mathrm{ab}}$ & $114^{\mathrm{a}}$ & 0.027 \\
Histidine & $89^{\mathrm{a}}$ & $93^{\mathrm{a}}$ & $90^{\mathrm{a}}$ & $92^{\mathrm{a}}$ & 0.056 \\
Valine & $25^{\mathrm{a}}$ & $18^{\mathrm{ab}}$ & $14^{\mathrm{b}}$ & $10^{\mathrm{b}}$ & 0.031 \\
Leucine & $60^{\mathrm{b}}$ & $70^{\mathrm{ab}}$ & $75^{\mathrm{a}}$ & $77^{\mathrm{a}}$ & 0.078 \\
Serine & $86^{\mathrm{a}}$ & $76^{\mathrm{ab}}$ & $60^{\mathrm{ab}}$ & $51^{\mathrm{b}}$ & 0.013 \\
Methionine & $58^{\mathrm{a}}$ & $54^{\mathrm{b}}$ & $60^{\mathrm{a}}$ & $62^{\mathrm{a}}$ & 0.104 \\
Isoleucine & $25^{\mathrm{a}}$ & $23^{\mathrm{a}}$ & $16^{\mathrm{b}}$ & $10^{\mathrm{b}}$ & 0.034 \\
Tyrosine & $48^{\mathrm{a}}$ & $43^{\mathrm{ab}}$ & $40^{\mathrm{b}}$ & $35^{\mathrm{b}}$ & 0.031 \\
Phenylalanine & $20^{\mathrm{a}}$ & $16^{\mathrm{ab}}$ & $12^{\mathrm{b}}$ & $10^{\mathrm{b}}$ & 0.022 \\
Lysine & $50^{\mathrm{ab}}$ & $46^{\mathrm{b}}$ & $53^{\mathrm{a}}$ & $55^{\mathrm{a}}$ & 0.033 \\
Alanine & $70^{\mathrm{a}}$ & $62^{\mathrm{a}}$ & $57^{\mathrm{ab}}$ & $44^{\mathrm{b}}$ & 0.027 \\
\hline$P$ value & $76^{\mathrm{b}}$ & $86^{\mathrm{a}}$ & $80^{\mathrm{a}}$ & $75^{\mathrm{b}}$ & 0.024 \\
\hline
\end{tabular}

Each value is the mean of three replicate, different letters in the same column and raw indicate statistically significant differences (significance level $P=0.05$ )

The highest aspartic acid and over average amino acids were found in Begumjangi and lowest in Dashtri (Fig. 3). Statistical analysis $(p=0.05)$ showed that proline, leucine, methionine, histidine, isoleucine, tyrosine, lysine, phenylalanine and alanine were noted slightly to highly significant different between the four investigated date palm varieties, but glycine serine, valine, exhibited non-significant variation. Similar observation was reported by Assirey (2015). They found variations in amino acid contents in different date varieties. Further that a normal level of amino acids is essential for human and it cannot be form in human body and it can be provided by diet (Al-Farsi et al., 2005).

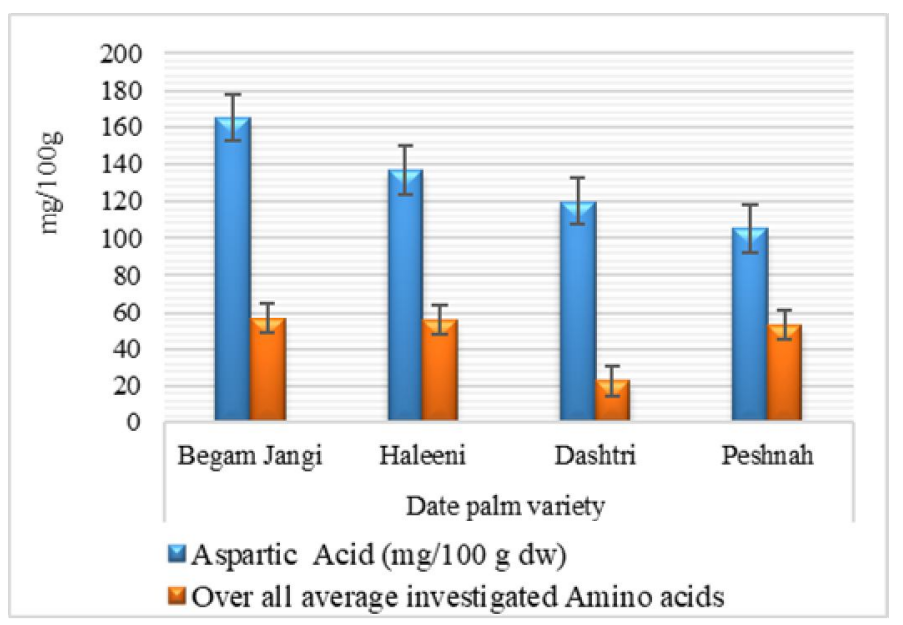

Figure 3. Aspartic Acid and Overall Ave. investigated Amino acids in date palm fruits 


\section{Fruit extract $\mathrm{pH}$ and total acidity}

Total acidity and $\mathrm{pH}$ in four date palm fruit varieties are shown in Fig. 4. The $\mathrm{pH}$ and total acidity in four observed date palm varieties were noted in ranged between 4.8 - 5.7 and $2.2-4.0 \mathrm{mg} / 100 \mathrm{~g} \mathrm{dw}$, respectively. The maximum $\mathrm{pH}$ and total acidity were found in Begumjangi and Peshnah, while minimum in Dashtri and Begumjangi juice respectively. The similar trend was observed by Reynes et al. (1994) in 21 date varieties from Tunisia.

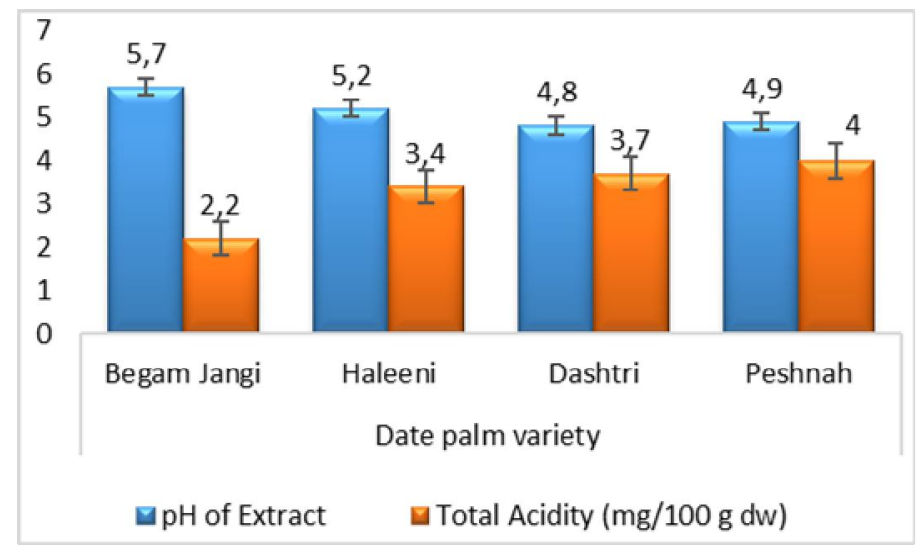

Figure 4. $\mathrm{pH}$ and Total Acidity date palm fruits

\section{Microbial Burden (cfu/g)}

Earlier investigation of microbial burden on examined date palm fruits varieties, the fruits were classified in to four size classes. The consequences of classification revealed that in large, medium, small and mixed size classes the number of fruits were in ranged of $38-84,45-125,69-167$ and 48 - 127, respectively. In all fruit size classes (large, medium, small and mixed) the maximum number of fruits were noted for Peshnah, followed by Dashtri, and Begamjangi and minimum was noted for Haleeni (Fig. 5). Variation in fruit size classes were also absorbed by Aleid (2014).

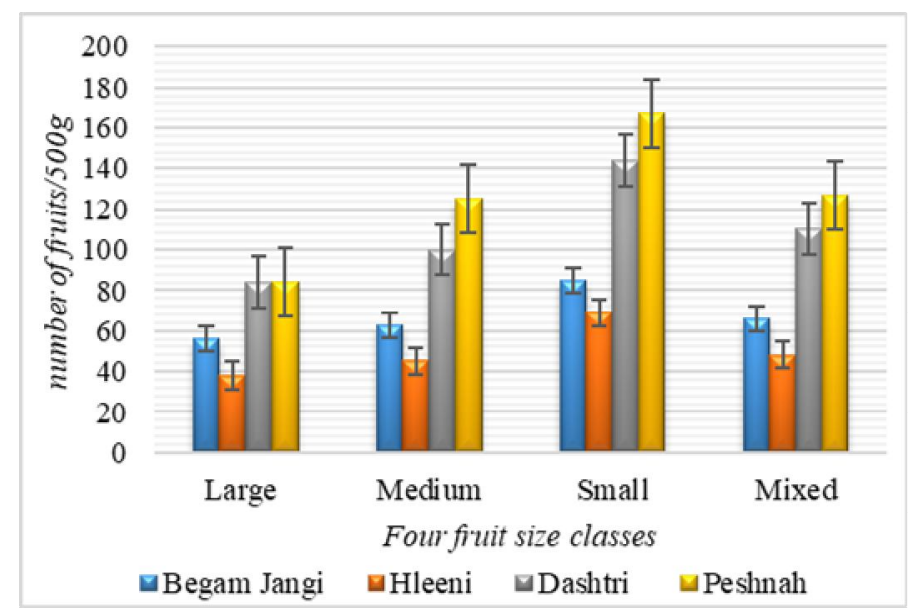

Figure 5. Classification of date palm fruits in to four size classes according to the number of fruits $/ 500 \mathrm{~g}$ 


\section{Microbial Burden (cfu/g) in un-pressed un-pitted dates fruits}

The results of un-pressed un- pitted dates fruits exhibited that in Begumjangi the microbial load (coliform VRBA, Moulds and yeast and Mesophilic aerobic bacteria) were found in the ranged $0.0-0.0,2.4-46.3$ and $25.4-196.3 \mathrm{cfu} / \mathrm{g}$ in four different fruit size classes, respectively. In Begamjangi the maximum microbial load was found by mesophilic aerobic bacteria, followed by moulds and yeast and minimum by Coliform VRBA. $P$ value indicated that different microbial organisms put highly significant different burden, similarly different fruit size classes showed highly significant variation in loads of Moulds and yeast and mesophilic aerobic bacteria but non-significant load of Coliform VRBA (Table 7). On Haleeni fruit the microbial i.e. Coliform VRBA, Moulds and yeast and Mesophilic aerobic Bacteria, load was recorded in between 0.0 - 3.4, 400.3 - 905.3 and 48.0 - $375.0 \mathrm{cfu} / \mathrm{g}$ for four fruit size classes (large, medium, small and mixed), respectively (Table 7). Statistical analysis indicated that there was highly significant variation between the fruit size classes as well as among the investigated microbial organisms at $p=0.05$ significant level (Table 7).

Table 7. Microbial Burden (cfu/g) in un-pressed un-pitted dates of four local verities of date palm

\begin{tabular}{|c|c|c|c|c|c|}
\hline \multirow[b]{2}{*}{ Date variety } & \multirow[b]{2}{*}{$\begin{array}{c}\text { Fruit Size } \\
\text { classes }\end{array}$} & \multicolumn{3}{|c|}{ Microbial variable } & \multirow[b]{2}{*}{$P$ value } \\
\hline & & Coliform VRBA & Moulds and yeast & $\begin{array}{l}\text { Mesophilic aerobic } \\
\text { bacteria }\end{array}$ & \\
\hline \multirow{5}{*}{ Begumjangi } & Large & $0.0^{\mathrm{b}}$ & $2.4^{\mathrm{b}}$ & $25.4^{\mathrm{b}}$ & 0.000 \\
\hline & Medium & $0.0^{\mathrm{b}}$ & $5.3^{\mathrm{b}}$ & $75.2^{\mathrm{ab}}$ & 0.000 \\
\hline & Small & $0.0^{\mathrm{b}}$ & $46.3^{\mathrm{a}}$ & $196.3^{\mathrm{a}}$ & 0.000 \\
\hline & Mixed & $0.0^{\mathrm{b}}$ & $20.37^{\mathrm{a}}$ & $102.66^{\mathrm{ab}}$ & 0.007 \\
\hline & $P$ value & 7.078 & 0.000 & 0.007 & \\
\hline \multirow{5}{*}{ Haleeni } & Large & $0.0^{\mathrm{b}}$ & $400.3^{b}$ & $48.0^{\mathrm{c}}$ & 0.000 \\
\hline & Medium & $0.0^{\mathrm{b}}$ & $662.0^{\mathrm{ab}}$ & $106.0^{\mathrm{b}}$ & 0.000 \\
\hline & Small & $3.4^{\mathrm{a}}$ & $905.3^{\mathrm{a}}$ & $375.0^{\mathrm{a}}$ & 0.000 \\
\hline & Mixed & $1.13^{\mathrm{b}}$ & $655.87^{\mathrm{ab}}$ & $176.33^{\mathrm{b}}$ & 0.000 \\
\hline & $P$ value & 0.000 & 0.000 & 0.005 & \\
\hline \multirow{5}{*}{ Dashtri } & Large & $0.0^{\mathrm{b}}$ & $28.0^{\mathrm{ab}}$ & $112^{\mathrm{c}}$ & 0.000 \\
\hline & Medium & $0.0^{\mathrm{b}}$ & $16.4^{\mathrm{b}}$ & $345^{\mathrm{b}}$ & 0.000 \\
\hline & Small & $2.1^{\mathrm{b}}$ & $53.2^{\mathrm{a}}$ & $712^{\mathrm{a}}$ & 0.000 \\
\hline & Mixed & $0.7^{\mathrm{a}}$ & $32.53^{\mathrm{a}}$ & $389.67^{\mathrm{b}}$ & 0.000 \\
\hline & $P$ value & 0.157 & 0.003 & 0.000 & \\
\hline \multirow{5}{*}{ Peshnah } & Large & $0.0^{\mathrm{c}}$ & $684.0^{\mathrm{a}}$ & $900.0^{\mathrm{b}}$ & 0.000 \\
\hline & Medium & $5.0^{\mathrm{b}}$ & $423.8^{\mathrm{b}}$ & $1200.0^{\mathrm{ab}}$ & 0.000 \\
\hline & Small & $53.7^{\mathrm{a}}$ & $100.2^{\mathrm{c}}$ & $1607^{\mathrm{a}}$ & 0.017 \\
\hline & Mixed & $19.57^{\mathrm{b}}$ & $402.67^{\mathrm{b}}$ & $1235.67^{\mathrm{ab}}$ & 0.000 \\
\hline & $P$ value & 0.000 & 0.0234 & 0.000 & \\
\hline
\end{tabular}

Each value is the mean of four replicate, different letters in the same column and raw indicate statistically significant differences (significance level $P=0.05$ )

In Dashtri fruit the Coliform VRBA, Moulds and yeast and Mesophilic aerobic Bacterial loads were found in the ranged of $0.0-2.1,16.4-53.2$ and $112-712 \mathrm{cfu} / \mathrm{g}$ in four fruit size classes, respectively. $P$ value indicated that the coliform VRBA was found non-significantly different between the classes and other two microbial organism was recorded with highly significant variation between the fruit size classes (Table 7).

Microbial (Coliform VRBA, Moulds and yeast and Mesophilic aerobic Bacteria) burden on Peshnah date palm fruits were from the ranged $0.0-53.7,100.2-684.0$ and 900.0 - $1600.7 \mathrm{cfu} / \mathrm{g}$, in large, medium, small and mixed fruit size classes respectively. 
The maximum load of Coliform VRBA was noted in small size class and minimum in large size class, but Moulds and yeast burden was noted highest in large and minimum on small size class. Mesophilic aerobic Bacteria was found highest in small size class which fallowed by mixed class and lowest in large size class (Table 7). Statistical analysis indicated that there was highly to slightly significant variation in response to microbial load between different date cultivar and fruit size classes at $P=0.05$ significant level (Table 7) in un-pressed un- pitted dates fruits. Among the classes overall investigated microbial load on four cultivar, was recorded highest burden for small fruit size class, followed by mixed and minimum was noted for large fruit size class (Fig. 6).

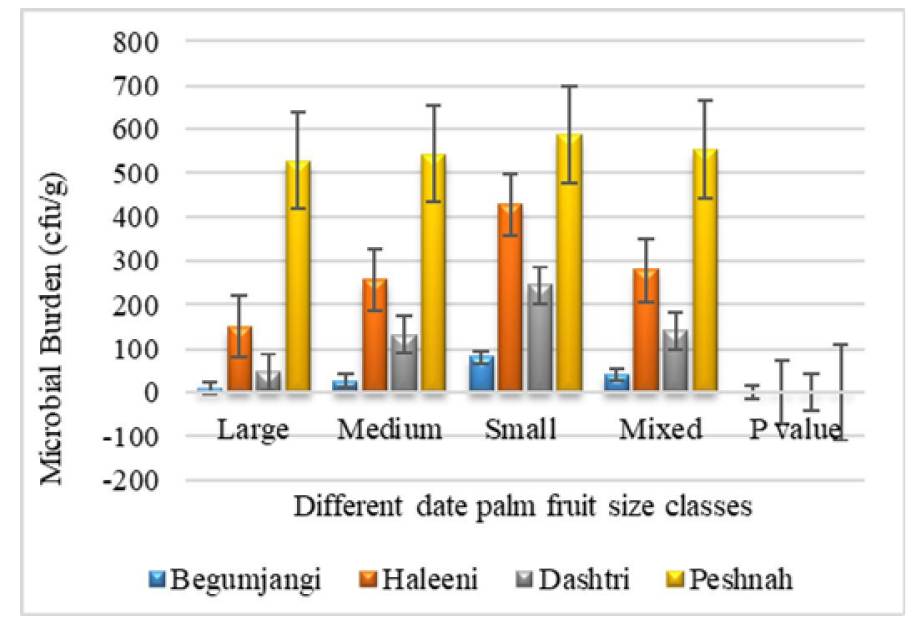

Figure 6. Overall Microbial Burden (cfu/g) in un-pressed-un pitted date palm varieties

\section{Microbial burden (cfu/g) in pressed-un pitted dates}

Microbial load in pressed-un pitted date fruit of Begumjangi was ranged between 100.0 - 296.0, 1660 - 2800 and 14.0 - $222 \mathrm{cfu} / \mathrm{g}$ for the Coliform VRBA, Moulds and yeast and Mesophilic aerobic Bacteria in different fruit size classes, respectively. On Haleeni fruit microbial load was recorded in between 22.0 - 56.7, 542.0 - 5000 and $180-500 \mathrm{cfu} / \mathrm{g}$ for the Coliform VRBA, Moulds and yeast and Mesophilic aerobic Bacterial in different fruits size classes, respectively and for Dashtri fruit it was found in range between 25.0 - 500.0, 1200.0 - 7807 and 387 - $1000.0 \mathrm{cfu} / \mathrm{g}$ for Coliform VRBA, Moulds/yeast and Mesophilic aerobic Bacteria in different fruits size class, respectively. Microbial burden on Peshnah fruit was noted in ranged between 74 - 433, 678 - 7000.0 and $400-1300 \mathrm{cfu} / \mathrm{g}$ for the Coliform VRBA, Moulds and yeast and Mesophilic aerobic Bacteria in different fruit size classes, respectively. The maximum microbial loads for all four cultivar were found in small size class, which fallowed by mixed and medium class and minimum was in large size class. Similarly Over all investigated microbial burden was noted in small size class which fallowed by mixed then medium and lowest was found for large size class. Statistically analysis indicated that there was highly significant variation among microbial infection in all fruit size classes but individual microbe showed slightly to non-significant variation between the classes (Table 8 and Fig. 7). Aleid (2014) reported that the small-sized fruits of Sukkary cultivar showed significantly $(\mathrm{P} \leq 0.05)$ higher counts for mesophilic aerobic bacteria and mould and yeasts than the larger or medium-sized fruits. In this investigation among the examined 
varieties Begamjangi was found hardest to microbial burden and peshnah was noted softed. Similar observation was also reported by Aleid (2014) during study of Microbial loads and physicochemical characteristics of fruits from four Saudi date palm tree cultivars: Conformity with Applicable Date Standards. Nussinovitch et al. (1989) found colony counts of soft dates in the order of $10^{4} \mathrm{cfu} / \mathrm{g}$ lactic acid bacteria. Aidoo et al. (1996) found bacteria, coliforms and moulds to be pollutants of dates (Tamr) bought from the stores with in greater Glasgow.

Table 8. Microbial burden (cfu/g) in pressed-un pitted dates of four local date palm varieties

\begin{tabular}{|c|c|c|c|c|c|}
\hline \multirow{2}{*}{ Date variety } & \multirow{2}{*}{$\begin{array}{c}\text { Fruit size } \\
\text { classes }\end{array}$} & \multicolumn{3}{|c|}{ Microbial variable } & \multirow{2}{*}{$P$ value } \\
\hline & & Coliform VRBA & Moulds and yeast & Mesophilic aerobic bacteria & \\
\hline \multirow{5}{*}{ Begumjangi } & Large & $100.0^{\mathrm{c}}$ & $1660^{\mathrm{c}}$ & $14.0^{\mathrm{c}}$ & 0.00 \\
\hline & Medium & $150.0^{\mathrm{b}}$ & $2047^{\mathrm{b}}$ & $107^{\mathrm{b}}$ & 0.00 \\
\hline & Small & $296.0^{\mathrm{a}}$ & $2800^{\mathrm{a}}$ & $222^{\mathrm{a}}$ & 0.00 \\
\hline & Mixed & $182.0^{\mathrm{b}}$ & $2169^{b}$ & $114.33^{\mathrm{b}}$ & 0.01 \\
\hline & $P$ value & $\mathbf{0 . 0 3 1}$ & 0.075 & 0.045 & \\
\hline \multirow{5}{*}{ Haleeni } & Large & $22.0^{b}$ & $542.0^{\mathrm{d}}$ & $180^{\mathrm{c}}$ & 0.00 \\
\hline & Medium & $34.2^{\mathrm{ab}}$ & $1086.0^{\mathrm{b}}$ & $323^{\mathrm{b}}$ & 0.00 \\
\hline & Small & $56.7^{\mathrm{a}}$ & $5000 .^{\mathrm{a}}$ & $500^{\mathrm{a}}$ & 0.00 \\
\hline & Mixed & $37.63^{\mathrm{ab}}$ & $2209.33^{\mathrm{c}}$ & $334.33^{\mathrm{b}}$ & 0.00 \\
\hline & $P$ value & 0.027 & 0.000 & 0.040 & \\
\hline \multirow{5}{*}{ Dashtri } & Large & $25.0^{\mathrm{c}}$ & $5630^{\mathrm{a}}$ & $387^{\mathrm{c}}$ & 0.00 \\
\hline & Medium & $150.0^{\mathrm{b}}$ & $7807^{\mathrm{a}}$ & $543^{\mathrm{b}}$ & 0.00 \\
\hline & Small & $500.0^{\mathrm{a}}$ & $1200.0^{\mathrm{b}}$ & $1000.0^{\mathrm{a}}$ & 0.00 \\
\hline & Mixed & $225 \mathrm{a}^{\mathrm{b}}$ & $4879^{a}$ & $643.33^{b}$ & 0.00 \\
\hline & $P$ value & 0.002 & 0.007 & 0.023 & \\
\hline \multirow{5}{*}{ Peshnah } & Large & $74^{\mathrm{d}}$ & $678^{\mathrm{c}}$ & $400^{c}$ & 0.00 \\
\hline & Medium & $158^{\mathrm{c}}$ & $7000.0^{\mathrm{a}}$ & $570^{\mathrm{b}}$ & 0.00 \\
\hline & Small & $433^{\mathrm{a}}$ & $10750^{\mathrm{a}}$ & $1300^{\mathrm{a}}$ & 0.00 \\
\hline & Mixed & $221.67^{b}$ & $6142.67^{\mathrm{b}}$ & $756.67^{b}$ & 0.00 \\
\hline & $P$ value & 0.006 & 0.000 & 0.000 & \\
\hline
\end{tabular}

Each value is the mean of four replicate, different letters in the same column and raw indicate statistically significant differences (significance level $P=0.05$ )

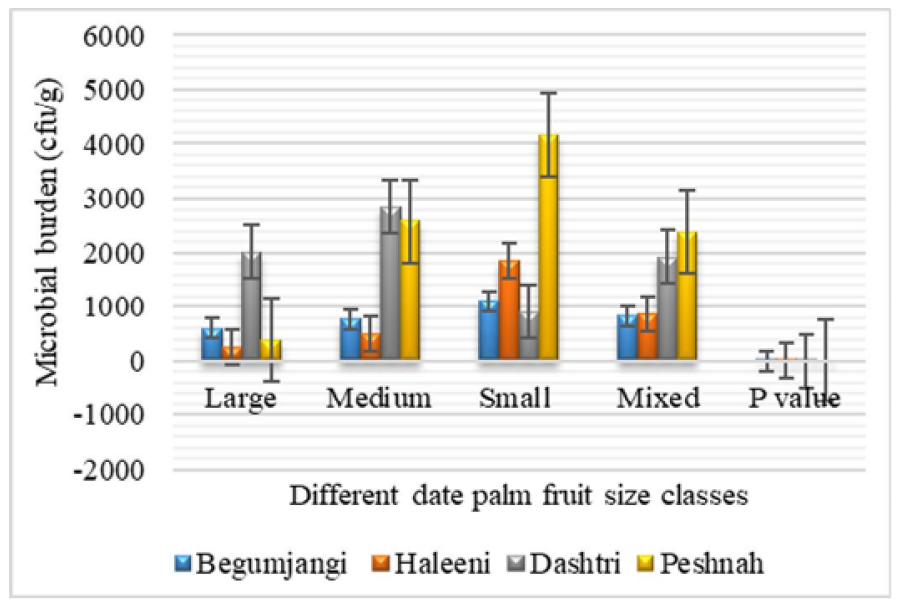

Figure 7. Over all microbial burden (cfu/g) in pressed-un pitted date palm varieties. In

Figures 2-7. bars on graphs showed standard error and statistically significant differences are at significance level $\mathrm{P}=0.05$. 
Kader (2007) reported that the microbial spoilage of dates (Tamr) can be caused by yeasts, moulds and bacteria. Abu-Zinada and Ali (1982) reported fungi contamination of different date (Tamr) varieties. Further that the dates contamination with microbial are eaten without further processing may represent a health risk for consumers, and therefore a food safety problem (Brandl, 2006; Hamilton et al., 2006; Tyler and Triplett, 2008). According to the Public Health Laboratory Services (PHLS, 1992, 1996) the Khalas, Sugai and Anbara dates showed unacceptable levels of coliform bacteria.

\section{Fruit Quality Assessment (FQA)}

Fruit Quality Assessment (FQA) through fruit performance index (FPI) and valuation classes indicated that the Begamjangi score highest grade point (6) and stand in excellent classes, which fallowed by Haleeni (4 grade point) with good class and other two dates cultivars Dashtri and Peshnah score 2.0 and 1.0 grade points and classified into poor and very poor category, respectively (Tables 9 and 10).

Table 9. Standard of grade point for fruit quality of date palm [references: Prajapati and Tripathi (2008); Govindaraju et al. (2012); Leghari et al. (2019)]

\begin{tabular}{c|c|c}
\hline Valuation classes & Scoring percentage & Grade point \\
\hline Not recommended & 30 & 0 \\
Very poor & $31-40$ & 2 \\
Poor & $41-50$ & 3 \\
Moderate & $51-60$ & 4 \\
Good & $61-70$ & 5 \\
Very good & $71-80$ & 6 \\
Excellent & $81-90$ & 7 \\
Best & $91-100$ & 7 \\
\hline
\end{tabular}

Table 10. Fruit Quality Assessment through fruit performance index (FPI) and valuation classes

\begin{tabular}{c|c|c|c|c|c}
\hline \multirow{2}{*}{ Quality Variables } & \multirow{2}{*}{ Values/Scale } & \multicolumn{4}{|c}{ Date Palm Varieties } \\
\cline { 3 - 6 } & & Begamjangi & Haleeni & Dashtri & Peshnah \\
\hline Fruit weight & $1-5$ & ++++ & +++++ & ++ & +++ \\
Stone weight & $1-5$ & ++++ & +++++ & +++ & ++ \\
Taste and flavor of fruits & $1-5$ & +++++ & ++++ & +++ & ++ \\
Acidity & $1-5$ & ++++ & +++ & ++ & + \\
Reducing Sugar & $1-5$ & +++++ & ++++ & +++ & ++ \\
Overall Minerals & $1-5$ & ++++ & +++ & ++ & + \\
Moisture/ Water activity & $1-10$ & ++++++++ & ++++++ & ++++ & +++ \\
Microbial burden hardy & $1-10$ & +++++++++ & ++++ & +++++ & ++ \\
Obtain Plus/50 & 50 & 43 & 34 & 24 & 16 \\
Score \%age & & 86 & 68 & 48 & 32 \\
Grade point & & 6 & 4 & 2 & 1 \\
\hline Valuation Classes & & Excellent & Good & Poor & Very poor \\
\hline
\end{tabular}

\section{Conclusion}

From the facts cited in this study it could be established that some significant performance characteristics were determined in the investigated dates palm fruits of Turbat, the results provide new information needed to adapt excellent dates standard for cultivation. A proportional examination of microbiological quality and physiochemical 
properties at the farm level, as well as a complete examination of current guidelines on date quality, are obligatory in order to review the significant quality criteria of date fruit standards. Moreover valuation of the investigated fruit performance or quality index is important for the dates of local area. The present study also concluded that the date variety Begamjangi and Haleeni due to their highest grade point and good financial worth are expected to be a decent performers and might be suggested for the cultivation.

\section{REFERENCES}

[1] Abekhti, A., Zarour, K., Boulal, A., Benmechernene, Z., Kihal, M. (2013): Evaluation of Microbiological Quality of the Date Fruit Product "Btana" Produced in Adrar South Algeria. - Journal of Microbiology Research 3(5): 163-170.

[2] Abu-Zinada, A. H., Ali, M. I. (1982): Fungi associated with dates in Saudi Arabia. Journal of Food Protection 45(9): 842-844.

[3] Ahmed, M. V. O. M., Bouna, Z. E. O., Lemine, F. M. M., Djeh, T. K. O., Mokhtar, T., Salem, A. O. M. (2011): Use of multivariate analysis to assess phenotypic diversity of date palm (Phoenix dactylifera L.) cultivars. - Scientia Horticulturae 127(3): 367-371.

[4] Aidoo, K. E., Tester, R. F., Morrison, J. E., MacFar- lane, D. (1996): The Composition and Microbial Quality of Pre- Packed Dates Purchased in Greater Glasgow. International Journal of Food Science \& Technology 31(5): 433-438.

[5] Aleid, S. M., Hassan, B. H., Almaiman, S. A., Al-Kahtani, S. H., Ismail, S. M. (2014): Microbial loads and physicochemical characteristics of fruits from four Saudi date palm tree cultivars: conformity with applicable date standards. - Food and Nutrition Sciences 5(04): 316-327.

[6] Al-Farsi, M., Alasalvar, C., Morris, A., Baron, M., Shahidi, F. (2005): Compositional and sensory characteristics of three native sun-dried date (Phoenix dactylifera L.) varieties grown in Oman. - Journal of agricultural and food chemistry 53(19): 7586-7591.

[7] Al-Farsi, M. A., Lee, C. Y. (2008): Nutritional and functional properties of dates: a review. - Critical reviews in food science and nutrition 48(10): 877-887.

[8] Al-Hooti, S., Sidhu, J. S., Qabazard, H. (1997): Physicochemical characteristics of five date fruit cultivars grown in the United Arab Emirates. - Plant Foods for Human Nutrition 50(2): 101-113.

[9] Anonymous. (2012): Food and Agriculture Organization (FAO). Retrieved 15th March 2014. - from http://faostat.fao.org/site/567/default.aspx\#ancor.

[10] AOAC. (1990): Official methods of analysis. - Association of Official Analytical Chemists.

[11] AOAC. (1995): Official Methods of Analysis. - 15th Edition, Association of Official Analytical Chemists, Washington DC.

[12] Ashraf, Z., Hamidi-Esfahani, Z. (2011): Date and Date Processing: A Review. - Food Reviews International 27: 101-133.

[13] Assirey, E. A. R. (2015): Nutritional composition of fruit of 10 date palm (Phoenix dactylifera L.) cultivars grown in Saudi Arabia. - Journal of Taibah University for science 9(1): 75-79.

[14] Atlas, R. M. (2004): Handbook of Microbiological Media. - 3rd Edition, CRC Press, Boca Raton, 2051 p. http://dx.doi.org/10.1201/9781420039726.

[15] Baliga, M. S., Baliga, B. R. V., Kandathil, S. M., Bhat, H. P., Vayalil, P. K. (2011): A review of the chemistry and pharmacology of the date fruits (Phoenix dactylifera L.). Food research international 44(7): 1812-1822.

[16] Besbes, S., Drira, L., Blecker, C., Deroanne, C., Attia, H. (2009): Adding value to hard date (Phoenix dactylifera L.): compositional, functional and sensory characteristics of date jam. - Food chemistry 112(2): 406-411. 
[17] Biglari, F., AlKarkhi, A. F., Easa, A. M. (2009): Cluster analysis of antioxidant compounds in dates (Phoenix dactylifera): Effect of long-term cold storage. - Food chemistry 112(4): 998-1001.

[18] Botes, A., Zaid, A. (2002): Date production support program. - FAO plant production and protection paper, 156, Rev. 1. FAO United Nations, Rome, Italy.

[19] Brandl, M. T. (2006): Fitness of human enteric pathogens on plants and implications for food safety. - Annu. Rev. Phytopathol 44: 367-392.

[20] Elleuch, M., Besbes, S., Roiseux, O., Blecker, C., Deroanne, C., Drira, N. E., Attia, H. (2008): Date flesh: Chemical composition and characteristics of the dietary fiber. - Food chemistry 111(3): 676-682.

[21] Folch, J., Lees, M., Sloane Stanley, G. H. (1957): A simple method for the isolation and purification of total lipids from animal tissues. - J. boil. Chem. 226(1): 497-509.

[22] Gasim, A. A. A. (1994): Changes in sugar quality and mineral elements during fruit development in five date palm cultivars in AI-Madinah AI-Munawwarah. - Journal of King Abdul Aziz University, Science 6: 29-36.

[23] Govindaraju, M., Ganeshkumar, R. S., Muthukumaran, V. R., Visvanathan, P. (2012): Identification and evaluation of air-pollution-tolerant plants around lignite-based thermal power station for greenbelt development. - Environmental Science and Pollution Research 19(4): 1210-1223.

[24] Haider, M. S., Khan, I. A., Jaskani, M. J., Naqvi, S. A., Hameed, M., Azam, M., Khan, A. A., Pintaud, J. C. (2015): Assessment of morphological attributes of Date palm accessions of diverse agro-ecological origin. - Pak. J. Bot. 47(3): 1143-1151.

[25] Hamilton, A. J., Stagnitti, F., Premier, R., Boland, A. M., Hale, G. (2006): Quantitative microbial risk assessment models for consumption of raw vegetables irrigated with reclaimed water. - Appl. Environ. Microbiol 72(5): 3284-3290.

[26] Hammadi, H., Mokhtar, R., Mokhtar, E., Ali, F. (2009): New approach for the morphological identification of date palm (Phoenix dactylifera L.) cultivars from Tunisia. - Pak. J. Bot. 41(6): 2771-2681.

[27] Iqbal, M., Rahman, U. U., Niamatullah, M., Khan, S. M., Akhtar, A. (2016): Periodic growth and development of fruits of different date cultivars grown under the agroclimatic conditions of DI Khan. - Pakistan Journal of Science (Pakistan) 64(3): 259-264.

[28] Jamil, M. S., Nadeem, R., Hanif, M. A., Ali, M. A., Akhtar, K. (2010): Proximate composition and mineral profile of eight different unstudied date (Phoenix dactylifera L.) varieties from Pakistan. - African Journal of Biotechnology 9(22): 3252-3259.

[29] Jaradat, A. A., Zaid, A. (2004): Quality traits of date palm fruits in a center of origin and center of diversity. - Journal of Food Agriculture and Environment 2: 208-217.

[30] Kader, A. A. (2007): Recommendation for Maintaining Post-harvest Quality. University of California, Davis, http://postharvest.ucdavis.edu/produce/fruit/dates.shtm.

[31] Langemeier, J. M., Rogers, D. E. (1995): Rapid method for sugar analysis of doughs and baked products. - Cereal chemistry (USA) 72: 349-351.

[32] Laurey, S. (1997): Protein structure core facility. - Omaha, NE, 68: 198-4525.

[33] Leghari, S. K., Asrar, M., Muhammad, A., Rahman, S., Ilahi, Z. (2017): Impact of Air Pollution Caused By Fire Smoke on Yield and Nutritional Value of Pleurotus (Flabellatus) Djamor, R-22. - Pak. J. Bot 49(SI): 279-282.

[34] Leghari, S. K., Akbar, A., Qasim, S., Ullah, S., Asrar, M., Rohail, H., Ahmed, S., Mehmood, K., Ali, I. (2019): Estimating Anticipated Performance Index and Air Pollution Tolerance Index of Some Trees and Ornamental Plant Species for the Construction of Green Belts. - Polish Journal of Environmental Studies 28(3): 17591769.

[35] Lemine, F. M. M., Samb, A., Zein-el-Abidine, O. B., Ahmed, M. V. O. M., Djeh, T. K. O., Boukhary, A. O. M. S. O. (2014): Assessment of physicochemical diversity in fruit of Mauritanian date palm (Phoenix dactylifera L.) cultivars. - African Journal of Agricultural Research 9(28): 2167-2176. 
[36] Mughal, S. A., Leghari, S. K., Achakzai, A. K. K., Asrar, M., Ismail, Ponya, Z., Rehman, S. R., Sadiq, N. (2018): Effects of road side pollution on physio-morphology of apple (Malus pumila Miller.) at District Kalat Balochistan, Pakistan. - International Journal of Biosciences 12(6): 334-345.

[37] Myhara, R. M., Karkalas, J., Taylor, M. S. (1999): Determination of the mineral compositions of some selected oil-bearing seeds and kernels using inductively coupled plasma atomic emission spectrometry (ICP-AES). - Grasas Aceites 57: 211-218.

[38] Nussinovitch, A., Rosen, B., Salik, H., Kopelman, I. J. (1989): Effect of Heating Media on the Microbiology and Shelf Life of Heat Pasteurized Soft Dates, Lebensmittel-Wissenschaftund. - Technologie 22(5): 245-247.

[39] Osman, A. M. A. (1984): The performance of date palms in the Sudan. - Acta Hort 143: 231-237.

[40] Piggott, J. R. (1995): Design Questions in Sensory and Consum-er Science. - Food Quality and Preference 6(4): 217-220.

[41] Prajapati, S. K., Tripathi, B. D. (2008): Anticipated Performance Index of some tree species considered for green belt development in and around an urban area: A case study of Varanasi city, India. - Journal of environmental management 88(4): 1343-1349.

[42] Public Health Laboratory Services (PHLS). (1992): Provisional Microbiological Guidelines for Some Ready-to-Eat Foods Sampled at Point of Sale, Notes for PHLS Food Examiners. - PHLS Microbiology Digest 9: 98-99.

[43] Public Health Laboratory Services (PHLS). (1996): Microbio-logical Guidelines for Some Ready-to-Eat Foods Sampled at the Point of Sale: An Expert Opinion from the PHLS. - PHLS Microbiology Digest 13: 41-43.

[44] Ragab, W. S., Ramadan, B. R., Sorour, M. A., Naglaa, A. (2011): Physical and Chemical Changes In Fruits of Three Dates Palm (Phoenix Dactylifera L.) Grown In South Valley Egypt. - Journal of Food and Dairy Sci., Mansoura Univ. 2(11): 605-615.

[45] Rahman, M. S., Al-Farsi, S. A. (2005): Instrumental Texture Profile Analysis (TPA) of Date Flesh as a Function of Moisture Content. - Journal of Food Engineering 66(4): 505511.

[46] Reynes, M., Bouabibi, H., Piombo, G., Risterucci, A. M. (1994): Characterization of the principal varieties of dates cultivated in the area of Djejrid in Tunisia. - Fruits 49: 289298.

[47] Safi, E. B., El Arem, A., Issaoui, M., Hammami, M., Achour, L. (2009): Phenolic content and antioxidant activity of four date palm (Phoenix dactylifera $\mathrm{L}$.) fruit varieties grown in Tunisia. - International journal of food science \& technology 44(11): 2314-2319.

[48] Sawaya, W. N., Miski, A. M., Khalil, J. K., Khatchadourian, H. A., Mashadi, A. S. (1983): Physical and chemical characterisation of the major date varieties grown in Saudi Arabia: I. Morphological measurements, proximate and mineral analyses. - Date Palm Journal 2: 1-25.

[49] Steel, R. G., Torrie, J. H. (1980): Principles and Procedures of Statistics. A Biometrical Approach. $-2^{\text {nd }}$ ed., McGraw-Hill, New York.

[50] Tyler, H. L., Triplett, E. W. (2008): Plants as a Habitat for Beneficial and/or Human Pathogenic Bacteria. - Annual Review of Phytopathology 46: 53-63.

[51] Vayalil, P. K. (2002): Antioxidant and antimutagenic properties of aqueous extract of date fruit (Phoenix dactylifera L. Arecaceae). - Journal of Agricultural and Food Chemistry 50(3): 610-617.

[52] Wills, R., McGlasson, B., Graham, D., Joyce, D. (1998): Post Harvest: An Introduction to the Physiology and Handling of Fruits, Vegetables and Ornamentals. - 4th Edition, University of New South Wales Press Ltd, Australia, 262 p.

[53] Zaid, A., de Wet, P. F. (2002): Origin, geographical distribution and nutritional values of date palm. - In: Zaid, A. (ed.) Date palm cultivation. Rev. Ed. Plant production and protection paper 156. Food and Agriculture Organization of the United Nations, Rome, pp 29-44. 
[54] Zehdi, S., Trifi, M., Billote, N., Marrakchi, M., Pintaud, J. C. (2005): Genetic diversity of Tunisian date palms (Phoenix dactylifera L.) revealed by nuclear microsatellite polymorphism. - Hereditas 141(3): 278-287.

[55] Zehdi, S., Cherif, E., Rhouma, S., Santoni, S., Hannachi, A. S., Pintaud, J. C. (2012): Molecular polymorphism and genetic relationships in date palm (Phoenix dactylifera L.): The utility of nuclear microsatellite markers. - Sci. Hortic. 148: 255-263. 